\title{
Rice Beer and tribes of Assam
}

\author{
Dr. Rabindranath Sarma \\ Centre for Tribal Folklore, Language and Literature. Central University of Jharkhand, Brambe, Ranchi- \\ 835205, India
}

\begin{abstract}
Assam is homeland of various local or tribal communities like Boro, Karbi, Mishing, Rabha, Deuri, Tiwa, Dimasa, Hajong, Garo, Khasi, Jaintia, Mech, Sonowal Kachari, Zeme Naga, Rengma Naga Kuki, Hmar etc. Rice is staple food of them. Home brewed rice beer is a must in the items of diet of almost all the tribal people of Assam. Rice beer is known with different names as per the different communities. Traditionally, Rice beer is using in many rituals.
\end{abstract}

Keywords: Rice beer, Tribe, Assam, Society, Culture

\section{INTRODUCTION}

Assam is homeland of various local or tribal communities like Boro, Karbi, Mishing, Rabha, Deuri, Tiwa, Dimasa, Hajong, Garo, Khasi, Jaintia, Mech, Sonowal Kachari, Zeme Naga, Rengma Naga Kuki, Hmar etc. Besides these, caste Hindu and Muslim people, tea garden and ex-tea garden laborers constitute Assamese society. Among these groups' elements of Indo-Mongoloid, Austric Dravidian and Aryan elements are found. According to B.Datta 'At present the bulk of the indigenous population is made up of Assamese Hindus among whom the Indo-Mongoloid or Kirata element is visibly strong in terms of both racial strains and cultural traits, although scholars have also discerned certain Austric and Dravidian ingredients...'(Datta, 1994:3-4)

In our present discussion we will consider only tribal groups of Assam.

Rice is staple food of them. Home brewed rice beer is a must in the items of diet of almost all the tribal people of Assam. According to Verrier Elwin, '... Rice beer holds an important place in the esteem of all the tribes. It is an essential element in the tradition of hospitality which is one of the most admired of tribal virtues; it is almost a medium of exchange; it has its share in most religious rituals; no tribal conference can succeed without it, it is the pledge that binds together those who make a pact of peace.' (Elwin; 1964:242). The aim of this paper is to study role or use of rice beer among various tribal communities of Assam and their perception to it. Library work and interview method has taken for this study.

Associating rice-beer with religious activities cannot be brushed aside as mere primitive practices. That sophisticated people also did so is supported by old religious texts. The Yogini Tantra enjoins:

\section{Na langhayet panadharmang deshadharmang no langhayet}

Yasmin pithe ya acharah sa acharo vidhismritah

('Any practice prevalent in a pitha $\{$ a part of Kamrupa $\}$ is to be lawful; $\{$ so $\}$ drinking and $\{$ other $\}$ practices of the land should not be dishonoured' )

It is also said that in worshipping Kameswari, an offering of blood, flesh and wine is must (rudhiromangsamaidyascha puzayt parameswarim). It also lays down that while worshipping Kamakhya local customs governing drink should not be disturbed and that wine must be accompanied by animal sacrifices. King Naranarayana of Coch-Behar offered wine among other things to Siva before he marched against the Ahoms. Mention may also be made here of the Mahabharata, wherein Durga has been described as a goddess fond of wine and flesh. (Das; 1999:39)

\section{MATERIALS AND METHODS}

Both primary and secondary sources were used to prepare the paper. Primary data have collected from the districts of Udalguri (for Rabha and Bodo), Hamren (for Karbi), Jonai (for Mishing), Kamrup (for Garo), Morigaon (for Tiwa), Diphu (Naga and Kuki groups), Tinsukia- Dibrugarh (for Deuri Sonowal-Kachari and Dimasa), Goalpara (for Mech) etc. Secondary data were collected from various books relating to different ethnic groups.

\section{RESULTS AND DISCUSSION}

Boro is a major tribal group of Assam who has a strong tradition of ricse-beer. "By far the most important occasion of merry-making in the social life of the Boro-Kacharis is the celebration of 'Baisagu' in the 
month of Baisakh (mid April).... The supreme deity 'Bathou' is also worshipped on this day by offering him chicken and rice-beer."(Bordoloi, Sharma Thakur and Saikia, 1987:9)

Rice-beer is very much essential liquor using in Boro marriage. In a marriage song, it is found the

women of the bride's side sing jokingly of the groom's arrangements:

Enjur mukhani gomothin

Nongni zoualay khoithin thin,

Khoithin thin.

Ukhum mudani cilimala,

Nongni zoualay melema.

Dabkha khibuni habru,

Nongni zoualay doibru buru.

(Brahma, 1960:p 24)

The cockroach of the wall of house

The rice-beer you have served is become sour extremely

At the house top a centipede clings;

No taste of your wine

There is mud on the rice-beer pot

You have must mixed water to treat this wine.

Boro people have sense of humour through folksong, which makes life enjoyable. A person impersonating a son-in-law in order to get good rice-beer receives a rebuff:

Barbuliya Barbuliya

Nongzamadoi phoidonmon

Zou goila?

Thuribarini gonca

Dohay longzobca!

(Brahma, 1960:p 32)

Hello Barbuliya, listen to me

Your son-in-law has arrived.

Haven't your liquor?

Come bring it out

And then Barbuliya replied

All that I possessed

The neighbours came and drank it off

The Boros think that Mahadeva first taught them how to brew rice-beer as a means of protecting human life; and he naturally asked for the first offering of jumai to be made to himself. It is no wonder then that the Boros will offer a pot of jumai in their variopus pujas.(Das,1999:38) The Deuri people use rice-beer (suze) and "they considered as the most valuable item for entertaining guests. Habit of taking tea is not popular among them. The elderly people take red tea without milk and sugar." (Bordoloi, Sharma Thakur and Saikia, 1987:25) The Deuris use sujhen in their household pujas. Their water deity is Jalkai Dangoria, who, when offended, has to be appeared with an elaborate ritual at the riverside and those who perform it can take nothing but sujhen.(Das,1999:38) The Dimasa-Kachari another Mongolian tribe of Assam. "The most favourable beverage of the Dimasas is rice-beer which they call zou. It is brewed at home. Sufficient quantity of zou is required for daily domestic consumption of the family members and also to entertain guests." (Bordoloi, Sharma Thakur and Saikia, 1987:49) The Karbis, belongs to Mongolian stock and live in Karbi Anglong district of Assam. "The most favourite beverage of the Karbis is rice-beer which is brewed by every family in their home. It is a orerequisite for the celebration of every festival whether social, religious or socio-religious. Similarly, it is also required in the observance of all religious rites. Guests are also entertained with rice-beer. Distilled liquor is also consumed by them occasionally."(Bordoloi, Sharma Thakur and Saikia, 1987:70) The Tiwas (Lalung) have two groups: plain Tiwas and Hill Tiwas and they also Mongolian group. According to Mr. Raghunath Senapati (83 years old of Baropujia of Marigaon district), Tiwa people believe that rice-beer sent to earth by Mahadeva, their supreme God and people drink it and use in their activities. They also knew that rice-beer is a liquor of God-gift. "The Lalungs take locally brewed rice-beer $(z u)$ in their day-to-day life. But of late consumption of rice-beer is fast disappearing among the plains Lalungs mainly due to economic reason. But rice-beer is an essential item in certain religious ceremonies. The educated section of the Lalungs discourages the rice-beer consumption and they take tea as beverage. Now-a-days guests are not entertained with $z u$ rather betel leaves and nuts and tea with or without sugar or milk are first items of reception of casual guests. Previously, at least till the fifties of this century a visitor to a Lalung village had to taste $z u$ as the refusal of $z u$ was considered as disrespect to the host and community. The hills Lalungs, however, still prefer $z u$. (Bordoloi, Sharma Thakur and Saikia, 1987:79) 
The Miris (Mishings) another Mongolian group who lived in northern upper Assam. "The apong (locally brewed rice-beer) serves as a drink and a food for everybody young or old, apong is considered to be prestigious item for entertaining the guests and every family should keep some apong to entertain guests. Preparation of rice beer is solely the women's business. The women who prepare apong are required to observe certain rules of ceremonial purity." (Bordoloi, Sharma Thakur and Saikia, 1987:108) The Rabhas are one of the major scheduled plain tribe of Assam and under greater Bodo linguistic stock. They are quite numerous in the southern bank of Assam in the belt stretching from Guwahati to Dudhnoi.(Das,1962:167) "Rice is the staple food of the tribe with an inherent liking for dried and powered fish, pork, and rice-beer (zonga). But the traditional likes and dislikes have now tended to disappear under economic pressure brought about by many factors. The consumption of rice-beer is also gradually coming down due to strict enforcement of the excise law, which is a healthy sign for the socio-economic growth of the society. It is now restricted manner and that too on occasions connected with some socio-religious rites and ceremonies."(Bordoloi, Sharma Thakur and Saikia, 1987:123) The Khoksi puja of the Rabhas is such a festival in which young men and women drink a lot for several days, go gay with dance and choose their life partners. The Rabhas also offer rice-beer to their dead in the grave. (Das, 1999:38)

The Hmar is another tribal group, residing in the North-Cachar hills district of Assam "A Hmar is not a habituated drinker. He drinks $z u$ (rice-beer) only when he has to entertain his friends. Besides he drinks $z u$ during the celebration of community festivals and to celebrate the successful hunting expeditions." (Bordoloi and Sharma Thakur, 1988: 30) The Kukis is also another group of Karbi Anglong and North-Cachar hills district of Assam. "A considerable quantity of rice is used by every family for the purpose of brewing ricebeer."(Bordoloi and Sharma Thakur, 1988: 53) "The Rengma Nagas of the Karbi Anglong perform a number of ceremonies that are connected with their cultivation - a) Nyada, b) Pi-pe, c) Lotsung-nga and d) khong kepang kennya." (Bordoloi and Sharma Thakur, 1988: 72-73). Rice-beer is used in all above-mentioned festivals. The Sonowal Kacharis residing in upper Assam and they also belongs to Mongolian group. "Rice-beer is locally prepared by families and the people take it occasionally. Today, however, the consumption of rice-beer is restricted and educated section prefers tea to rive-beer. Formerly the first item to entertain guests was betel leaves and nuts and rice-beer and the host seemed to be offended when the guests refused to accept their hospitality. Their trend is fast disappearing and now-a-days tea is offered to the guests." (Bordoloi and Sharma Thakur, 1988: 83) The Zeme Nagas is another Naga group of Assam. "Rice-beer called ijaduijang is the most favourite drink. It is required for the entertainment of guests, home consumption in the performance of religious rites and during the community feasts." (Bordoloi and Sharma Thakur, 1988: 110)

Rice is staple food of the Garos of Assam. "Rice-beer is the most favourite drink for the Garos. They rather use it as a kind of nutritious food and the young ones have a taste of it from the time of their mothers use to carry them on their back. But those who have accepted Christianity, disfavour drinking of rice-beer." (Bordoloi, 1991: 13) The Garos, especially their young people, will drink and dance all through the night in their festivals connected with agriculture. For the Jaintia people of Assam Rice-beer is the favourite beverage and they use it in marriage ceremony and other feasts. The Khasis are Mongoloid people, including the Jaintias who speak Mon-Khmer language living in Karbi Anglong and North Cachar hills district of Assam. "The Khasis drink not only rice-beer and beer made from the root of a plant called Khawiang but also other alcoholic drinks." (Bordoloi, 1991: 74) According to Ms. L.Syiem there is a Khasi proverb songsit khawiang which means unbalance person. The Meches are Mongolian people found in western and extreme eastern part of Assam. "Their most favourite drink, however, is rice-beer brewed at home. There is no hard and fast rule as to when and how much rice-beer callesd jau one should drink or consume. Rice-beer is a must in the performance of socio-religious festivals as well as for the entertainment of guests. Offering of jou to Bathu (Siva) is, of course, a taboo."(Bordoloi, 1991: 90)

\section{CONCLUSION}

After all, traditionally, most of the tribal people of Assam use rice beer. Rice is the staple food in the entire region. Paddy cultivation is common to all. At one time, home-brewed rice-beer is a must in the items of diet of almost all the tribal people of Assam. But at present people have given their own choice whether they will drink or not. This rice-beer they also offer to their gods and goddesses. Earlier, they offer to guest's too and the refusal of rice beer was considered as disrespect to the host and community. Each tribe has a name for ricebeer of its own, but there is a similarity in the sound of these names. The Garos call it su, the Deuris sujhen, the Boros jou or jumai, the Mishimis $y u$ etc. The Boros think it has a medicinal power; anybody having stomach trouble or suffering from physical weakness will surely come round after drinking a few cups of juami. The Deuris say they drink sujhen as frequently as the urban folk drink tea. Most of the people offer rice beer to their guests. Some of these people believe that rice-beer has a divine origin. 


\section{REFERENCES}

[1] Datta, B. A Handbook of Folklore of Material of Assam (ABILAC, Guwahati-24, 1994)

[2] Elwin, V. A Philosophy for NEFA (Department of Research, Arunachal Pradesh Itanagar, 1964)

[3] Das,J. Folklore of Assam (National Book Trust, New Delhi-110016, 1999(1972))

[4] Bordoloi,B.N. Saikia, M.C. and Sharma Thakur,G.C. Tribes of Assam Part-I (Tribal Research Institute, Guwahati-781028, 1987)

[5] Barua,B.K.\& Hussien,R. Nutritive Value of Undistilled Rice-beer Journal of The University of Gauhati vol. IX no2:Science 1958

[6] Brahma,M.M. Folksongs of the Bodos (Publication Department, Gauhati University, Guwahati-14, 1960)

[7] Das, B.M. The Rabhs, in M.Neog (ed.) Asomor Janajati (Asom Sahitya Sabha, Jorhat 1962)

[8] Das, B.M. The Rabhs, in M.Neog (ed.) Asomor Janajati (Asom Sahitya Sabha, Jorhat 1962)

[9] Bordoloi,B.N. Saikia, M.C. and Sharma Thakur,G.C. Tribes of Assam Part-I (Tribal Research Institute, Guwahati-781028, 1987)

[10] Bordoloi,B.N. Saikia, M.C. and Sharma Thakur,G.C. Tribes of Assam Part-I (Tribal Research Institute, Guwahati-781028, 1987)

[11] Bordoloi,B.N. Saikia, M.C. and Sharma Thakur,G.C. Tribes of Assam Part-I (Tribal Research Institute, Guwahati-781028, 1987)

[12] Das, B.M. The Rabhs, in M.Neog (ed.) Asomor Janajati (Asom Sahitya Sabha, Jorhat 1962)

[13] Bordoloi,B.N. Saikia, M.C. and Sharma Thakur,G.C. Tribes of Assam Part-I (Tribal Research Institute, Guwahati-781028, 1987)

[14] Bordoloi,B.N. Saikia, M.C. and Sharma Thakur,G.C. Tribes of Assam Part-I (Tribal Research Institute, Guwahati-781028, 1987)

[15] Bordoloi,B.N. Saikia, M.C. and Sharma Thakur,G.C. Tribes of Assam Part-I (Tribal Research Institute, Guwahati-781028, 1987)

[16] Bordoloi,B.N. Saikia, M.C. and Sharma Thakur,G.C. Tribes of Assam Part-I (Tribal Research Institute, Guwahati-781028, 1987)

[17] Bordoloi,B.N. Saikia, M.C. and Sharma Thakur,G.C. Tribes of Assam Part-I (Tribal Research Institute, Guwahati-781028, 1987) 